\title{
7 The challenge of Indigenous data in Sweden
}

\author{
Per Axelsson and Christina Storm Mienna
}

\section{Introduction}

The traditional land of the Indigenous Sami people — known as Sápmi/Sábme/ Sábmie/Saepmie, depending on the Sami language - is situated in the northern parts of Norway, Sweden, Finland and Russia. The size of the Sami population is estimated at between 75,000 and 120,000, with the majority living in Norway (Young \& Bjerregaard 2019; Bartlett et al. 2007; Axelsson \& Sköld 2011). Systems for collecting Sami population data are today non-existent and as a result, the Sami are invisible in official statistics (Axelsson et al. 2016). Subsequently, the knowledge of the Sami health situation is limited (Storm Mienna \& Axelsson 2019).This statistical erasure is consistent across all countries inhabited by the Sami people.

Based on the "Ethnicity Counts database (eCount)", Mullane Ronaki (2017) investigated Indigenous Peoples' recognition in censuses globally and determined that systems for identification ranged from fixed categories to self-identification and that less than half of all Indigenous Peoples are still not recognized by their nation states. The Nordic countries and Russia fall into the "less than half" category. In a widely cited study on Indigenous and Tribal Peoples' health, Anderson et al. (2016) reported that 15 of 22 countries reported health and social data on Indigenous Peoples in their national systems. Furthermore, it was obvious that the CANZUS states maintained the best possibilities to accumulate a variety of data on Indigenous Peoples based on the system of self-definitions in censuses. The report concluded that data was a general concern and that "National governments should develop targeted policies for Indigenous and tribal health that address issues of health service delivery and the development of high-quality Indigenous data systems". Hence, there is little data produced by the state that the Sami can use and have the opportunity to take ownership of. Indigenous data that do exist are mainly produced by researchers and guarded by Swedish ethical protocols that do not take Sami ownership or control into account (Drugge 2016). Questions around Indigenous data ownership and control have yet not been on the political agenda in Sweden.

In Sweden, the focus of this chapter, the absence of state-collected Sami population data means that the government cannot provide any comprehensive 
understanding of the health and well-being of its only Indigenous People. This circumstance has repeatedly been criticized by international agencies but also from political institutions within the Sami society (Madden et al. 2016). The Organization for Economic Co-operation and Development report Linking the Indigenous Sami People with Regional and Rural Development in Sweden (OECD 2019), acknowledges that statistics have sometimes been criticized for poorly capturing key elements of Indigenous Peoples' lives, worldviews and societies. However, the statistical invisibility of the Sami severely hampers policy making and ways of knowing if policies are effective and legal requirements are met. The OECD recommended that Sweden, among other things, should "synthesize current data sources and identify data limitations in its use and dissemination", "increase research funding for Sami data collection" and "develop ethical guidelines for research on Sami" (OECD 2019, 54-55).

However, things have recently progressed due to increased pressure from Sami society and non-governmental organizations that have called for a truth and reconciliation commission (Sametinget 2019); ethical guidelines for Sami research (Kvernmo et al. 2018); a consultation order for Sami issues (Regeringen 2019); and enhancing the Sami Parliament's role and possibilities to collect data (OECD 2019). Together with the implementation of a Nordic Sami Convention (Sametinget 2019) it may open up discussions on ownership and governance of data. Meanwhile, there is limited knowledge of what Sami society thinks of recent, but increasingly influential, global discussions on Indigenous Data Sovereignty. This chapter, the first study based on material from focus group discussions from the HALDI project, examines how Sami people perceive and reflect upon the importance of control and ownership of data generated in Sami research.

\section{The Haldi project—data and method}

Despite a lack of governmental data in the Nordic countries, there are successful examples of population-based research such as the SAMINOR study led and governed by the Centre for Sami Health Research at the Arctic University of Norway (UIT). The SAMINOR study includes ethnic self-identification (Brustad et al. 2014) and the study comprises both a questionnaire and a clinical study that has run in two waves in selected municipalities in traditional Sami areas of northern Norway. The SAMINOR study has so far resulted in 52 peer-reviewed articles, eight $\mathrm{PhD}$ theses and extensive reports to participating municipalities describing the current health status in Norwegian Sápmi (Lund et al. 2007; SAMINOR 2020).

In 2018, the Swedish government funded a focus group study to prepare for a population-based research project called "HALDI - health and living conditions in Sápmi, Sweden". The HALDI project collaborates with the SAMINOR study and will be based on the international recommendation of ethnic self-identification (United Nations 2017, 203-206). The idea behind HALDI was initiated in 2015 and the following year the project obtained collective consent from the Sami Parliament in Sweden. The project is divided into different stages where the 
first stage involved focus group discussions (Marczak \& Sewell 2006; Krueger \& Casey 2014) in order to give Sami in Sweden room to broadly discuss issues relating to Sami health and what future health and well-being research is required. The results from the focus group discussions will be used in the second stage of the HALDI project and provide input to the questionnaire and the clinical examinations. The focus group project was approved by the Regional Ethical Review Board of Umeå, Sweden (Dnr 2017/408-31).

\section{Sami perspectives on the ownership and governance of Sami health data}

In 1977, the Swedish government recognized the Sami as an Indigenous People, in 1993, the Sami Parliament in Sweden was established and in 2011, the Sami people became recognized as a people in the Swedish constitution. These were unquestionably important achievements for the Sami people. At the same time, things went in the opposite direction concerning Indigenous data. A few years after the Swedish government had recognized the Sami as an Indigenous People in Sweden, the Data Act (1973:289, especially Prop 1981/82:189) established that the processing of data that reveals ethnicity or race was prohibited. Further research is needed, but when this regulation was introduced in 1982 there seemed to have been no arguments or discussions around expected shortcomings for the Sami people. The Data Act has been modified over time and currently sits under the General Data Protection Regulation (GDPR) within the European Union.

International governing instruments such as the United Nations Declaration of the Rights of Indigenous Peoples (UN General Assembly 2007) introduced in 2007 and eventually adopted by 148 countries have the potential to make states engage with Indigenous Peoples in meaningful ways to change the current state of affairs. For instance, Article 18 states that:

Indigenous peoples have the right to participate in decision-making in matters which would affect their rights, through representatives chosen by themselves in accordance with their own procedures, as well as to maintain and develop their own Indigenous decision-making institution.

Moreover, the Sustainable Development Goals clearly states that more data is needed to be able to monitor the progress among Indigenous Peoples and ethnic groups (Balestra \& Fleisher 2018). Despite this, few attempts have been made to improve data collection on issues relating to Indigenous or ethnic groups in Sweden as well as most of western Europe. There certainly are methodological and pragmatical issues that need to be solved to ensure ethnic data collection in western Europe (Simon 2017). Why is western Europe different? Simon (2017) summarized how in post-Second World War western Europe data on "race" and "ethnicity" was ignored because not only did it echo the countries' complex colonial histories, but it risked fragmenting the nation and undermining "social and political cohesion" and that "ethnic statistics reify and reinforce ascribed identities which are unstable and flexible" (Simon 2017, 2328). 
Furthermore, the Nazi regime used demographic records to identify and locate ethnic groups, mainly Jews, for deportation to concentration camps (Luebke \& Milton 1994). Adding to that, there was the science of racial biology that was strong, especially in Sweden in the first half of the 20th century. It is now common knowledge that demographic records collected by the state and the church were used in research to separate civilized "Nordic" races from the primitive "Indigenous Sami" races that was believed would soon die out (Axelsson 2010). This research was evidently done without any informed consent from the individuals affected by it and has remained an open wound, not only by the generation that lived through the Second World War and the era of racial biology but up until generations today (Heith 2015). Moreover, as late as 2013 it was discovered that Swedish police kept a secret register of Roma people (Axelsson 2015). The public reactions were of outrage and the Swedish state was convicted of ethnic discrimination in 2017 (Civil Right Defenders 2017). This made collection of ethnic statistics, an already sensitive topic, even more controversial and challenged the notion that the Swedish state could be trusted with the governance of any form of ethnic data. It is important to be aware of this historical backdrop to be able to understand the results from our focus group study.

A total of 11 focus group discussions were held in Sápmi, in northern Sweden during autumn 2018 and spring 2019. The focus group participants consisted of a diverse group of Sami individuals regarding gender, age and occupation. In total, 51 individuals participated in the group discussions. Two-thirds were women and the age spanned from 23 to 77 years of age. Before the focus group started every participant signed an informed consent form and the discussions were audio-recorded (ranging in duration between 28 and 117 minutes) and later transcribed verbatim. The discussions were mainly in Swedish and when Sami language was spoken, it was later translated and transcribed to Swedish. The transcriptions were analyzed according to content analysis described by Graneheim and Lundman (2004) and at a later stage reported back to each focus group for corrections and confirmation. The discussions focused on a variety of perspectives on health, well-being and health research, aiming to generate knowledge of issues relevant for the Sami people in Sweden and the upcoming health survey in particular. One section, or theme, was devoted to the issue of Indigenous data and governance of produced research data. The main question was who should own or govern the data produced in a future health research study with Sami participants' material.

The focus groups discussion that followed around this theme showed a diversity in opinions both between different groups but also between individuals in the same focus group. A pervading opinion in the groups was that data management about Sami people was of significant importance to building trust and acceptance in research. Regarding what governing body should be considered the owners of health research data, three suggestions emerged in the focus groups: the Sami Parliament, the healthcare authorities and the universities. Using quotes from the focus groups the following section illustrates some of the main arguments in each case. (See Swedish transcript in Appendix.) 


\section{The Sami Parliament}

Even if there were individuals that expressed doubts that the Sami Parliament was the right authority to have the guardianship of research data, the majority thought that the Sami Parliament was the correct place for keeping and managing data, especially human biological materials.

The Sami data should be under the auspices of the Sami Parliament.

The current obstacles with management of "ethnic data" also became evident.

The Sami society should be owners, but we lack that sort of arrangement in Sweden, to make it possible.

Aware of the difficulties of Indigenous data, there were opinions that a Sami health institution should be established in Sweden. Some focus groups held the position that Sami committees or Sami organizations could also serve as potential guardians.

You have to think that there is a need for a specific Sami health institution. This [institution] would have some kind of overall control of what happens and what it looks like, what needs to be done ... . The most natural may be ... or the most desirable would be that the Sami Parliament had some sort of overarching responsibility ... as it now stands it might be difficult, though, to know how the Sami Parliament would be able to take care of it.

\section{The healthcare authorities}

Swedish healthcare authorities were mentioned by a few as possible owners of collected research data regarding health issues in Swedish Sápmi. However, it was considered important that data would be made easily accessible for future research and societal development.

There must be some kind of an outcome. I mean, you do not do it just to get a paper that no one will have access to.

Some participants expressed distrust of the Swedish health system and perceived institutions to lack the required competence and understanding of Sami culture and living conditions.

Regarding Sami health, the Regional health care authorities should have begun long ago. Because we are citizens too. And we, and the health care system, should welcome all citizens based on their situation and their needs. And today they don't. And that ... it has been ignored. Due to ignorance, due to cowardice, due to prejudice, yes, whatever it is. Financial reasons. 


\section{The universities}

For some of the participants, the ownership of Sami data was not an issue to be contested. They argued that, if they had given their consent to a study, the researchers could keep that data and use it whenever and however they saw fit, could manage Indigenous data and would see to it that laws and regulations were fulfilled.

It feels safer if a university is responsible, I think it is safer.

Participants in these focus groups trusted that universities could manage data safely and securely.

\section{Historical legacies}

Another issue that originated from the discussions of data and data management had to do with previous data registers collected in the name of science or the state and sometimes both.

Several focus groups expressed a fear that the data risked being used in a wrong or damaging way for the Sami people, hence they were afraid of being identified as Sami in future data registers. Because of that, participants thought that the data should be owned and managed by Sami authorities.

What we see today, how it has ... been used in the wrong way. I have thought of it, with measurements of skulls and everything, that it has made you ... you become a little afraid of how, ... how will it, as mum said, be used against us. Instead of making progress. Well, that's the fear I see. And that is why it is extremely important that ... all material is Sami owned.

There were a few examples of individuals that had no hesitation or fear that data collection such as medical records or data registers could be misused. A few individuals expressed that any research that could help inform society about Sami health outweighed the eventual risk of data being exposed. However, regardless of the question of ownership, focus group participants brought up the history of racial biology in Sweden as well as the persecution of Jews during the Second World War in connection with discussions about science and data registers.

In the old days, when you researched something it became a register and you used it in some way. [...] And the same thing was the case, when the Sami Parliament was established, yes, now we will need to register as Sami. But ... I also wondered, what happens then? Then there will be a register of us Sami. And then "they" will take it. It will be like the Jews in Germany during the Nazi era. But that discussion has completely disappeared.

Some focus groups acknowledged the fear or research and registers but also highlighted and commented on the status quo that currently surrounds these questions. 
You are a little scared, and everyone, many Sami people are probably afraid to participate in surveys, because we have the legacy of race biology. We have Hitler and Jews. And many do not enroll in the Sami Parliament, older people, because they do not want to be registered. So we have something we deal with. But, but if we do not line up and participate in such things [...] it will never be investigated.

Participants also expressed opinions that all research data should, as soon as it has been used, be destroyed or "reburied". This opinion was linked to an ongoing process of repatriation of Sami human remains in Sweden. In the 1950s an old Sami burial ground was excavated and 25 skulls were sent to the National History Museum in Stockholm for further research. These skulls were brought back to Sápmi and reburied in Liksjoe (Lycksele) in August 2019. (Radio Sweden 2019).

And I mean, in the end you must have looked at it enough so that you have learned what to see. Then you need to return it in an honorable way. And in the meantime, I think I ... then there should be strong ethical ... guidelines for it. And one is that the Sami material, it must, yes, in some way be the protected by the Sami Parliament, or something like that.

The focus group participants were consistent in their explicit views that Sami research material and Sami research data should ideally be governed by Sami themselves and that researchers should seek permission to use it for research and the beneficence of the Sami people. At the same time, given the current circumstances and resources, it was obvious that participants expressed doubts if the Sami Parliament currently possessed the capacity to manage and govern health research data.

The results from the focus group discussions point to the Sami Parliament being considered the most credible authority to have the guardianship of research data regarding health issues linked to the Sami people. It was also evident that the participants thought that data should be owned and managed by Sami themselves, but recognized that no such system was currently in place to make that happen. If data would be managed by the Swedish healthcare system, people with competence in Sami culture and living conditions should be involved in the process and the decision making. Finally, it is obvious that the history and experiences of racial biology and Nazi Germany plays important roles in how science and data are perceived in Sápmi, in Sweden today.

\section{Discussion}

While the histories of the aftermath of the Second World War and racial biology linger and conceivably are reasons for the reluctance to do anything to meet the demands of Indigenous Peoples and ethnic groups that want and need accurate population statistics - the call for Indigenous Data Sovereignty has grown rapidly. Indigenous Data Sovereignty (IDS) has shifted the international 
conversation beyond data disaggregation, identification and access to consider issues of Indigenous Peoples' governance, ownership and control. The right of Indigenous Peoples to control data from and about their communities and landsarticulating both individual and collective rights to data access and to data privacy has been advocated by IDS networks worldwide (Kukutai \& Taylor 2016; Raine et al. 2017; Rodrigues-Lonebear 2016) and also corresponds with the requests by the Sami people participating in the focus group discussions.

The focus group study carried out in late 2018 and early 2019 confirms that there is an existing fear among participants that science and research data involving Sami individuals, families and groups might be used for the wrong purposes, especially if data are stored in systems outside of Sami control. However, data management regarding humans has yet to be put on the political agenda of the Sami Parliament, but there are developments in a number of related areas. The Sami Parliament has established an ethical board, whose task is to develop advisory guidelines on issues relating to the return, storage and re-burial of Sami remnants in Sweden. Nevertheless, the ethical board has, at the time of writing, no responsibilities in research policy matters.

The Parliament has, by the Swedish state, been given the mandate to operate a system for managing regional statistical data-but only data that concerns the reindeer industry. The data concerns the number of reindeer owners, the size of herds, slaughter, the number of predators in reindeer herding areas and so on (Samediggi Rennäring 2017). There is still nothing in relation to official population statistics but there is a tendency of increasing focus on capacity building within the Parliament. In 2018, a committee responsible for health, the elderly and sports was established and in late November 2019, the Sami Parliament plenary adopted a health policy program. This program contained a call to the Swedish government to give the Sami Parliament the mandate to work with health issues (currently the Parliament lack that mandate) with accompanying increased funding. Nine areas were identified (not necessarily in this order): (1) language-and culture adapted health care, student health and care (2) public health work (3) research and center for Sami health research (4) accessible health care (5) influence (6) increased diversity and tolerance (7) national Sami health center (8) truth and reconciliation committee (9) implementation the UN Declaration on the Rights of Indigenous Peoples (Samediggi 2019). The Sami Parliament in Sweden has also responded to the Swedish government proposal for research policy where it was argued that the future Swedish research policy should target Sami research and establish research ethical guidelines for Sami research enabling comparative research in the four countries that include Sápmi (Samediggi 2019). Furthermore, Sámiid Riikkasearvi (SSR), a Sami organization in Sweden has developed and adopted a policy regarding research when collaborating with their organization (Sámiid Riikkasearvi 2019). All these actions can be seen as a conscious direction toward increased Sami self-determination in several questions regarding research, data management, health and ethics.

Although the Collective benefit Authority to control Responsibility Ethics (CARE) principles for Indigenous Data Governance (Global Indigenous Data 
Alliance) within the IDS are devoted to data ecosystems, some of the principles fit well with the current discussion on research ethics in Sápmi. It is probably in this space where the discussion on IDS most likely will advance in Sweden and Scandinavia. A proposal of ethical guidelines for Sami health research and research on Sami human biological material have been put forward by a group of researchers together with the Sami Parliament in Norway. This document includes recommendations on carrying out research on/with Indigenous Sami (Kvernmo et al. 2018). Just as in the CARE principles, the proposal for ethical guidelines state that research should respect the values and reflect the diversity in the Sami culture and the Sami society, avoid stereotyping, benefit Indigenous communities, provide equal partnership and strengthen the Sami community at large.

Relations between the Sámi communities and the researchers must be characterised by respect, reciprocity, equality, accountability, cultural assurance and Sámi self-determination in every research project, regardless of the project's objectives, design or method. These values are based on recognition and appreciation of the Sámi as a people and on respect for their integrity.

(Kvernmo et al. 2018, 40)

However, the CARE principles have a stronger commitment to the authority to control, community use of data and capacity building than the proposed ethical guidelines. Particularly, the "authority to control" also resonated with the participants in the focus groups. However, they expressed doubts if the Sami Parliament currently possessed the capacity to manage and govern health research data. A main point with the Indigenous Data Sovereignty movement is to design and maintain relevant data for policy work in important areas of the society. If, for instance, the Sami Parliament would express a strong need for solid demographic data for planning their future, and also found ways to collect, store and manage this information, should not the state consider this? What is needed at the moment is a focus on IDS, reliable and increased funding and time for the Sami parliament to be able to build an active leadership regarding the governance of Indigenous data beyond reindeer husbandry.

\section{Acknowledgment}

We would like to thank all focus group participants across Sápmi, Sweden. Furthermore, we want to thank Eleonor Blind, Lena Maria Nilsson, Tobias Poggats and Petter Stoor for their help during the interviews. Thanks also to the researchers at the Várdduo - Centre for Sami research, Umeå University for commenting on the focus group guide. We also would like to express our thanks to the editors of the book and the reviewers for suggestion and comments to improve this chapter. This study was funded by the Swedish ministry of health and social affairs (dnr: S2018/03552/FS) and the Wallenberg Academy Fellowship (KAW 2012.0222 Axelsson). 


\section{References}

Anderson, I., et al. (2016). "Indigenous and tribal peoples' health (The Lancet-Lowitja Institute Global Collaboration): a population study.” The Lancet, 388(10040), 131-157.

Axelsson, P. (2010). "Abandoning 'the other'-statistical enumeration of Swedish Sami 1700s-1945 and beyond." Berichte zur Wissenschaftsgeschichte, 33, 263-279.

Axelsson, P., \& Sköld, P. (2011, paperback 2013). Indigenous Peoples and Demography. The Complex Relation between Identity and Statistics. Oxford and New York, NY: Berghahn Books.

Axelsson, P. (2015). "Urfolkshälsa —utmanande och svårfångad." Socialmedicinsk Tidskrift, 92(6), 726-735.

Axelsson, P., Kukutai, T., \& Kippen, R. (2016). "Indigenous wellbeing and colonization: editorial." Journal of Northern Studies, 10(2), 7-18.

Balestra, C., \& Fleischer, L. (2018). Diversity Statistics in the OECD: How do OECD Countries Collect Data on Ethnic, Racial and Indigenous Identity, OECD Statistics Working Papers, No. 2018/09, OECD Publishing, Paris, France.

Bartlett, J.G., et al. (2007). "Identifying Indigenous peoples for health research in a global context: a review of perspectives and challenges." International Journal of Circumpolar Health, 66(4), 287-307.

Brustad, M., Hansen, K.L., Broderstad, A.R., Hansen, S., \& Melhus, M. (2014). “A population-based study on health and living conditions in areas with mixed Sami and Norwegian settlements - the SAMINOR 2 questionnaire study." International Journal of Circumpolar Health, 2014, 73.

Civil Right Defenders. (2017). Historic Court Ruling: Swedish State Guilty of Ethnic Registration. https://crd.org/2017/04/28/historic-court-ruling-swedish-state-guilty-of -ethnic-registration/.

Drugge, A.-L. (2016). "How can we do it right?: ethical uncertainty in Swedish Sami research." Journal of Academic Ethics, 14, 263-279.

Global Indigenous Data Alliance. https://www.gida-global.org/care [accessed February 2, 2020].

Graneheim, U.H., \& Lundman, B. (2004). "Qualitative content analysis in nursing research: concepts, procedures and measures to achieve trustworthiness." Nurse Education Today, 24, 105-112.

Hälsopolitiskt Handlings Program. https://www.sametinget.se/halsopolitik.

Heith, A. (2015). "Enacting colonised space: Katarina Pirak Sikku and Anders Sunna." Nordisk Museologi, (2), 69-83.

Hemställan om Sanningskommission Inlämnad. https://www.sametinget.se/129187.

Kotljarchuk, A. (2017). "World war II and the registration of Roma in Sweden: the role of experts and census-takers." Holocaust and Genocide Studies, 31(3), 457-479. https:// www.muse.jhu.edu/article/682455.

Krueger, R.A., \& Casey, M.A. (2014). Focus Groups: A Practical Guide for Applied Research. Sage Publications.

Kue Young, T., \& Bjerregaard, P. (2019). "Towards estimating the indigenous population in circumpolar regions." International Journal of Circumpolar Health, 78, 1. doi:10.1 080/22423982.2019.1653749.

Kukutai, T., \& Taylor, J. (Eds.) (2016). Indigenous Data Sovereignty: Toward an Agenda. Canberra, Australia: Australian National University Press.

Kvernmo, S., et al. (2018). Proposal for Ethical Guidelines for Sámi Health Research and Research on Sámi Human Biological Material. Karasjok, Norway: Sámediggi. 
Luebke, D., \& Milton, S. (1994). "Locating the victim: an overview of census-taking, tabulation technology and persecution in Nazi Germany." IEEE Annals of the History of Computing, 16(3), 25. doi:10.1109/MAHC.1994.298418.

Lund, E., et al. (2007). "Population based study of health and living conditions in areas with both Sami and Norwegian populations - the saminor study." International Journal of Circumpolar Health, 66(2), 113-128. doi:10.3402/ijch.v66i2.18241.

Madden, R., Axelsson, P., Kukutai, T., Griffiths, K., Storm Mienna, C., Brown, N., Coleman, C., \& Ring, I. (2016). "Statistics on indigenous peoples: international effort needed." Statistical Journal of the IAOS, 32(1), 37-41.

Marczak, M., \& Sewell, M. (2006). Using Focus Groups for Evaluation. Cyferbet Evaluation. Tucson, AZ: The University of Arizona.

Mullane-Ronaki, M.-T.T.K.K. (2017). Indigenising the National Census? A Global Study of the Enumeration of Indigenous Peoples, 1985-2014. Thesis, Master of Social Sciences (MSocSc), University of Waikato, Hamilton, New Zealand. Retrieved from https://hdl.handle.net/10289/11175.

Nordic Saami Convention. https://www.sametinget.se/105173.

OECD. (2019). Linking the Indigenous Sami People with Regional Development in Sweden, OECD Rural Policy Reviews, OECD Publishing, Paris. doi:10.1787/9789264310544-en.

Proposition 1981/82:189 Om ändring i Datalagen m.m. webaccess: https://www.riksdage n.se/sv/dokument-lagar/dokument/proposition/om-andring-i-datalagen-1973289-mm G503189/html.

Radio Sweden. (2019). Largest Reburial in Swedish History as Sami Remains Laid to Rest (Broadcast 2019-08-09). https://sverigesradio.se/sida/artikel.aspx?programid=2054\&a rtikel $=7277599$.

Rainie, S.C., Schultz, J.L., Briggs, E., Riggs, P., \& Palmanteer-Holder, N.L. (2017). "Data as strategic resource: self-determination and the data challenge for united states native nation and tribes." International Indigenous Policy Journal, 8(2). doi:10.18584/ iipj.2017.8.2.1. http://ir.lib.uwo.ca/iipj/vol8/iss2/1.

Regeringen. (2019). Remiss av Utkast till Lagrådsremiss En Konsultationsordning $i$ Frågor som rör det Samiska Folket. Diarienummer: Ku2019/01308/RS. https://www .regeringen.se/remisser/2019/07/remiss-av-utkast-till-lagradsremiss-en-konsultations ordning-i-fragor-som-ror-det-samiska-folket/ [accessed March 20, 2020].

Rennäring. https://www.sametinget.se/rennaring.

Rodriguez-Lonebear, D. (2016). "Building a data revolution in Indian country." In Indigenous Data Sovereignty: Toward an Agenda, edited by T. Kukutai, \& J. Taylor. Canberra, Australia: Australian National University Press.

Sámediggi-The Sami Parliament in Sweden. Webpages [accessed February 2, 2020].

Sámiid Riikkasearvi. (2019). Policy Regarding Research and Project Collaborations with Sámiid Riikkasearvi. Sámiid Riikkasearvi.

SAMINOR Webpage Publications. https://uit.no/forskning/forskningsgrupper/sub?p_d ocument id $=425187 \&$ sub_id $=617617$ [accessed February 2, 2020].

Samisk Forskning i Svensk Forskningspolitik. https://www.sametinget.se/135662.

Simon, P. (2017). The failure of the importation of ethno-racial statistics in Europe: debates and controversies. Ethnic and Racial Studies. 40. 1-7. 10.1080. /01419870.2017.1344278.

Storm Mienna, C., \& Axelsson, P. (2019). "Somatic health in the indigenous Sami population - a systematic review." International Journal of Circumpolar Health, 78(1), 1638195. doi:10.1080/22423982.2019.1638195. 
Svensk Författningssamling. (1973). Datalagen, p. 289. https://www.riksdagen.se/sv/do kument-lagar/dokument/svensk-forfattningssamling/datalag-1973289_sfs-1973-289.

United Nations. (2017). Principles and Recommendations for Population and Housing Censuses Revision 3. New York, NY: Department of Economic and Social Affairs, p. 205.

UN General Assembly. (2007). United Nations Declaration on the Rights of Indigenous Peoples: Resolution/Adopted by the General Assembly, October 2, 2007, A/ RES/61/295. https://www.refworld.org/docid/471355a82.html [accessed February 2, 2020].

\section{Appendix: quotations transcribed in Swedish from HALDI Focus Group}

Det samiska materialet ska på något sätt stå under Sametingets beskydd.

Den samiska miljön är det som ska vara ägare, men vi har inte någon form av sådan i Sverige, som skulle vara möjlig att vara ägare av det.

Men man måste ju tänka sig att det behövs en särskild samisk hälsoinstitution. Som har någon slags övergripande koll på vad som händer och hur det ser ut, vad som behöver göras.... Det naturliga kanske är ... eller det mest önskvärda vore ju att Sametinget hade någon sorts paraplyansvar om det.... $i$ det här läget kan det ju vara svårt och så, veta, hur Sametinget ska ta hand om, kunna ta hand om den, som det ser ut nu, då.

Fast det måste ju komma ut någonting. Alltså, och man gör ju inte det bara för att få ett papper som ingen ska ha tillgång till.

För att det här med samisk hälsa, det borde ju landstingen ha påbörjat för länge sen. För vi är ju medborgare vi också. Och vi, och vården ska ju möta folk utifrån deras situation och deras behov. Och i dag gör de inte det. Och det, man har som struntat i det. Av okunskap, av feghet, av fördomar, ja, allt vad det är. Kostnadsskäl.

Det känns tryggare att det är något universitet som ansvaret, jag tycker det känns tryggare.

Det vi ser idag, hur man har ... använt det på fel sätt. Jag har tänkt på det, med skallmätningar och allting, att det har gjort att man blir ... man blir lite rädd över hur, hur ... hur ska det, och lite grann som mamma sa, att använda det emot oss. I stället för att leda saken framåt. Det är väl den rädslan jag ser. Och därför är det oerhört viktigt att det är ... allt material är i samisk ägo.

Är det som gammalt, då ska man ta reda på och så blir det register och man använder det på något sätt. [---] Och samma sak var det ju, Sametinget inrättade, ja, nu ska vi registrera som samer. Men ... det var ju också som man undrade, vad händer då? Då blir det register på vem som är samer. Och sen tar de, det blir liksom med judarna i Tyskland under nazitiden. Men den diskussionen har ju helt försvunnit.

Man är ju lite rädd, och alla, många samer är nog rädda att delta $i$ undersökningar, eftersom vi har det är arvet med rasbiologin. Vi har Hitler och judar. Och många skriver inte in sig $i$ Sametinget, äldre, för att de vill inte stå registrerade. 
Så vi har ju någonting vi lever under. Men, men om vi inte ställer upp och är med på sådana grejer, så blir det ju att det finns, det blir aldrig undersökt.

Och jag menar, till slut måste man väl ha tittat så att man har lärt sig vad man ska se, va. Då ska man ju på ett hedersvärdigt sätt återbörda det. Och under tiden så tycker jag att jag ... då ska ju finnas en väldiga etiska ... riktlinjer för det. Och ett är ju att det samiska materialet, det ska ju, ja, stå under på något sätt Sametingets beskydd, eller någonting sådant där. 